\title{
Wstęp
}

\section{Poza wyobraźnią, ponad polityką}

Justyna Tabaszewska

TEKSTY DRUGIE 2020, NR 6, S. 7-15

DOI: 10.18318/td.2020.6.1 | ORCID: 0000-0001-9077-8817

1

Rok 2020, który zamyka niniejszy numer „Tekstów Drugich", był dla nas wszystkich co najmniej wyzwaniem. Używam tego ostrożnego słowa, bo zarówno z powodów pandemicznych, jak i politycznych będzie zapewne jednym z częściej dyskutowanych i ocenianych - przypuszczalnie w zróżnicowany sposób okresów wciąż jeszcze młodego stulecia. Dla wielu jest to rok osobistych tragedii i zagrożenia, dla niemal wszystkich - czas niepokoju i frustracji. Pandemia koronawirusa chyba każdego wybiła z dotychczasowego rytmu i pokazała, że przyszłość może być nieprzewidywalna, nawet jeśli była i przewidywana, i w przeszłości przeżyta. Zaskoczenie wywołane przez pierwszą od lat pandemię (choć przecież wcale nie pierwszą choćby w powojennej historii), może być wydarzeniem formacyjnym dla całych pokoleń, które będą patrzyć w przyszłość zdecydowanie mniej ufnie, niż poprzednie generacje, a niewykluczone, że i mniej będą ufać własnym intuicjom dotyczącym tego, co może stanowić realne zagrożenie. Kiedy otwieraliśmy rok 2020 numerem poświęconym m.in. koncepcji apokalipsy i postapokalipsy, za główne wydarzenie i zarazem zagrożenie „nadprogowe" naszych czasów (a więc nie notowane nie dlatego, że jest zbyt drobne, lecz dlatego że przekracza nasze ramy pojmowania jako

\section{Justyna}

\section{Tabaszewska -} adiunkt, autorka książek Jedna przyroda czy przyrody alternatywne? O pojmowaniu i obrazach przyrodyw polskiej poezji i Poetyki pamięci. Współczesna poezja wobec tradycji i pamięci oraz artykułów publikowanych m. in. w "Tekstach Drugich" $i$ „Przeglądzie Kulturoznawczym". Pracuje w Instytucie Badań Literackich nad projektem „Afektywne poetyki pamięci. Polska literatura i kultura wobec przełomu roku 1989." Kontakt: justyna.tabaszewska@ibl.waw.pl 
za wielkie)' uznawaliśmy katastrofę ekologiczną związaną ze zmianą klimatu. Epidemie, pandemie oraz powstawanie nowych typów wirusów okazały się kolejnym - przepowiadanym, wieszczonym, ale równocześnie przeoczanym - zagrożeniem, jednocześnie nadprogowym (bo zakres i skutki pandemii przekraczają naszą wyobraźnię) oraz podprogowym (bo przywykliśmy upatrywać niebezpieczeństw w tym, co wielkie i złożone, a nie w opanowanym, wydawałoby się, przez współczesną medycynę świecie mikrobów, bakterii oraz wirusów). Rzeczywistość pokazała nam jednak, jak niedoceniany potencjał apokaliptyczny tkwi w tym, co "bio".

Ostatni tegoroczny numer "Tekstów Drugich" nie jest jednak poświęcony tematowi pandemii. Wydarzenie to jest jeszcze zbyt świeże, by zostało w pełni wyrażone w którymkolwiek z mediów kultury i zaczęło rezonować w koncepcjach teoretycznych, choć pojawiają się pierwsze odpowiedzi na pandemiczny kryzys ${ }^{2}$, a i wcześniej istniało całe spektrum koncepcji, które mierzyły się z tego typu zagrożeniem jako co najmniej możliwym. Czym innym jest jednak możliwość, a czym innym - realne doświadczenie, odnoszące się do wydarzenia, które nie jest jeszcze przecież zamknięte ani zakończone. Jednak i ono wcześniej czy później ulegnie mediatyzacji, i przyjdzie nam zmierzyć się z tekstowo wyrażonymi skutkami pandemii, jej społecznymi oraz politycznymi reperkusjami. Ten numer opowiada właśnie - za pośrednictwem artykułów odmiennych koncepcyjnie i dotyczących innych problemów - o wyzwaniu mierzenia się literatury z tym, co polityczne.

Terminu "polityczność" używam tu oczywiście w najszerszym z możliwych sensów, w którym polityczne jest to, co publiczne, a sam fakt decydowania, co staje się publiczne, jest polityczny ze swojej natury³. O ile w globalnym ujęciu rok 2020 będzie zapewne pamiętany przez pryzmat pandemii, o tyle w lokalnym, polskim kontekście pandemię przyćmić może pamięć o - i tu znowu brakuje mi słowa, więc użyję najbardziej neutralnego z możliwych - zmianach w prawie do aborcji. Orzeczenie Trybunału

1 Por. artykuł P. Mościckiego Apokalipsa Teraz!, „Teksty Drugie” 2020 nr 1 oraz G. Andersa Die Antiquiertheit des Menschen (1956), C.H. Beck, München 1961, S. 263.

2 Por. m.in. S. Žižek Pandemic! Covid-19 Shakes the World, OR Books, New York 2020; M. Foucault, G. Agamben, J.L. Nancy, R. Esposito, S. Benvenuto, D. Dwivedi, S. Mohan, R. Ronchi, M. de Carolis Coronavirus and philosophers, "The European Journal of Psychoanalysis" 2020; https://www.journal-psychoanalysis.eu/coronavirus-and-philosophers/ (dostęp: 10.10.2020); G. Agamben The Invention of an Epidemic, "The European Journal of Psychoanalysis" 2020, https://www.journal-psychoanalysis. eu/coronavirus-and-philosophers/ (dostęp: 10.10.2020.); G. Agamben The State of Exception Provoked by an Unmotivated Emergency, "Positions Politics" 2020, http://positionswebsite.org/giorgioagamben-the-state-of-exception-provoked-by-an-unmotivated-emergency/ (dostęp: 10.10.2020); I. Krastev Is it Tomorrow Yet? Paradoxes of the Pandemic, Allen Lane, London 2020.

3 Por. m.in. Ch. Mouffe Polityczność. Przewodnik krytyki politycznej, przeł. J. Erbel, Wydawnictwo Krytyki Politycznej, Warszawa 2008; C. Schmitt Teologia polityczna i inne pisma, przeł. M. Cichocki, Aletheia, Warszawa 2000. 
Konstytucyjnego, wskazujące na niezgodność z Konstytucją RP jednej z trzech przesłanek umożliwiających legalną aborcję w Polsce, wywołało niezwykle gwałtowną - jeśli mierzyć ją liczbą protestujących - reakcję polityczną w nowoczesnej Polsce. Dla wielu - w tym i dla mnie - największą z tych, w których przyszło im uczestniczyć i które dane im było zaobserwować w życiu.

Ponownie, jest to wydarzenie, które zostawi swój ślad w literaturze, kulturze i szeroko rozumianej humanistce z pewnym opóźnieniem. I ponownie, jest to wydarzenie, które większość społeczeństwa zaskoczyło bezprecedensowo, choć przecież precedens miało, choćby i w znikającej w 1993 roku czwartej przesłance, umożliwiającej legalną aborcję.

Wspominam o tych dwóch krzyżujących się wydarzeniach: pandemii oraz zmianie w prawie do aborcji, ponieważ łączą się one w moim osobistym przeżyciu w jedno przejmujące, a zarazem przekraczające wyobraźnię doświadczenie: pozbawienia kontroli nad własnym ciałem, nagle wystawionym na obiektywne, w tym wirusowe zagrożenie, a jednocześnie poddanym ścisłej kontroli i reżimowi, co z jednej strony wynika z usprawiedliwionej potrzeby opanowania pandemii, a z drugiej - z moim zdaniem nieusprawiedliwialnego przekonania, że niektóre ciała, zwłaszcza kobiece, należą nie do jednostek, ale do sztucznie stworzonej wspólnoty. W obu przypadkach akt sprawowania kontroli ma charakter ściśle polityczny, choć wynika z odmiennych pobudek i potrzeb.

Piszę na ten temat we wstępie do nowego numeru „Tekstów Drugich" nie tylko po to, by w jakiś sposób oddać realia później jesieni roku 2020, ale też po to, by pokazać, w jaki sposób polityka jest częścią najbardziej intymnych doświadczeń (stając się biopolityką w najściślejszym znaczeniu tego sformułowania), takich chociażby jak odczuwanie własnego ciała jako nagle obcego, zagrażającego (bo mogącego roznosić wirusy) i zarazem zagrożonego (bo zależnego od cudzych, czasem całkowicie arbitralnych decyzji). To doświadczenie jeszcze kilkanaście miesięcy temu przekraczało granice mojej wyobraźni, a teraz staje się elementem kształtującym - być może nie tylko moją - tożsamość.

Wydarzenia, które przekraczają naszą wyobraźnię, w tym polityczną, dzieją się zwłaszcza w Polsce - częściej, niż sugerowałaby logika tego sformułowania. I o tym właśnie, o funkcjonowaniu polityki oraz wyobraźni, a także o przekroczeniach, do których dochodzi w każdej z tych sfer i na ich przecięciu, opowiada ten numer.

\section{2}

Teoretyków nacjonalizmu wprawiały zazwyczaj w zakłopotanie, jeśli nie w irytację, trzy następujące sprzeczności;1) między obiektywnie niedawnym, zdaniem 
historyków, ukształtowaniem się narodu a ich subiektywną dawnością, zdaniem nacjonalistów; 2) między formalną uniwersalnością narodowości jako pojęcia społeczno-kulturowego (w świecie nowożytnym każdy może, powinien i będzie "mieć" narodowość, tak jak „ma" płeć) a nieuchronną partykularnością jej konkretnych przejawów; 3) między „polityczną| potęgą nacjonalizmu a jego filozoficzną miałkością, a nawet niespójnością ${ }^{4}$.

Tematem przewodnim co najmniej kilku tekstów zamieszczonych w sekcji Szkice jest to, jak konceptualizujemy polskość i jak definiujemy naród. Przytoczony wyżej cytat z klasycznej już pracy Benedicta Andersona dobrze wprowadza w paradoks związany z pisaniem i mówieniem na temat tych pojęć oraz zapowiada kłopoty czekające każdego, kto zamierza wypowiadać się na temat konkretnej narodowości. Problemy mnożą się dodatkowo, gdy przedmiotem dyskusji jest istota danej narodowości, a więc w tym przypadku nie tylko naród polski, ale polskość jako taka. W takiej sytuacji bardzo trudno - nawet gdyby postawić to sobie za cel - zachować neutralność lub apolityczność, i to nawet gdyby polityczność definiować już wcale nie tak szeroko, jak proponowałam na początku tego tekstu. Proste odnotowanie faktu, że naród jest pojęciem o wcale nie tak długiej historii, a w dodatku konstruktem pojęciowym, który - jak każdy konstrukt - musi być historycznie zmienny oraz podlegać ewolucji, najczęściej traktuje się już jako deklarację polityczną. Dopowiedzenie, że nagła ekspansja pojęcia i jego niewątpliwa nośność wcale nie gwarantują trwałości, a koncepcja „narodu” może zdezaktualizować się w podobnym tempie jak to, w którym zawładnęła społeczną wyobraźnią, bywa już rozumiane jako otwarte wyzwanie.

Z tej perspektywy pierwszy z prezentowanych w tym numerze bloków tekstów ma charakter nie tylko polityczny, ale wręcz wywrotowy, ponieważ zajmuje się negocjowaniem rozumienia nie tylko kategorii narodu, lecz właśnie polskości. Szkice otwierają dwa artykuły poświęcone wizjom polskości: Stefan Chwin analizuje krytykę, której empiryczny naród polski poddają Czesław Miłosz i Zbigniew Herbert, Andrzej Franaszek zaś interpretuje skomplikowaną relację z polskością (i ze sobą nawzajem) Józefa Czapskiego i znów Czesława Miłosza. Nie chcę tu streszczać wspomnianych artykułów, ale zwrócę uwagę na kwestię teoretycznie oczywistą: na polityczne ugruntowanie koncepcji „polskości” oraz fakt, że jej definicja zależy zawsze od konstruktora pojęcia.

To, jak postrzegana jest polskość lub bycie Polakiem - co pokazują nie tylko przywoływane artykuły - bezpośrednio zależy od kilku czynników. Po pierwszego, od tego, czy mowa o realnie istniejącym w danym momencie historycznym narodzie, czy też o zdecydowanie bardziej ogólnej (i zarazem podatnej na przekształcenia oraz manipulacje) 
idei. Podejmowana w części publikowanych tu tekstów krytyka „polskości” dotyczy najczęściej tego realnie istniejącego, empirycznego narodu, który - jako wspólnota - bywa bardzo niechętny wobec prób rozliczania z równie realnych decyzji oraz zaniedbań. Sposobem na przezwyciężenie lub zamknięcie możliwości jakiejkolwiek krytyki jest właśnie odwoływanie się do idei narodu oraz idei polskości definiowanej w samych superlatywach. Zgodnie z taką logiką, każde odstępstwo od ideału ma wyłącznie charakter incydentalny i nie wpływa - a przynajmniej wpływać nie powinno na ideę narodu. Używając ponownie sformułowań Stefana Chwina, naród idealny jest wyobrażeniem odpowiadającym raczej temu, jak być powinno i jak chcielibyśmy się jako naród widzieć, niż odbiciem rzeczywistości. Bytem realnym jest natomiast naród empiryczny, a więc wspólnota narodowa, która rzeczywiście zaistniała w określonych warunkach historycznych. Krytyka wspólnoty empirycznej jest jednak najczęściej traktowana nie jako droga zbliżenia tych dwóch wspólnot do siebie, lecz jako atak na to idealistyczne i w zamyśle wspólnototwórcze postrzeganie narodu i polskości.

Zmieńmy nieco repertuar pojęć - wydaje się, że ta polskość, która jest obecnie dyskutowana, nie ma już wiele wspólnego ze wspólnotą empiryczną, z określoną zbiorowością. Nie jest jednak - tak przynajmniej uważam - tylko idealistycznym przełożeniem wyobrażeń na temat tego, czym naród polski i polskość mogłyby być, na język polityki i retoryczno-społecznej komunikacji. Jest raczej sposobem budowania wspólnoty wyobrażonej, opierającej się nie na dążeniu do pozytywnych wzorców, lecz na negacji. Używam tu dobrze znanego pojęcia Andersona, by wytłumaczyć połączenie w tytule tego numeru dwóch pojęć: wyobraźni i polityki.

Skoro przedmiotem polityki jest kształtowanie narodu jako wspólnoty wyobrażonej, a to, jak ta wspólnota jest konstruowana, wpływa wtórnie nie tylko na dyskusje polityczne, lecz również na sposób funkcjonowania realnego, empirycznego narodu, warto zadać pytanie, czy to samonapędzające się koło idealizacji narodu przez negację wszystkich niepasujących do akceptowalnego obrazu cech i wydarzeń oraz przez wyłączanie poza obręb wspólnoty wszystkich dowolnie definiowanych „innych" może się zakończyć inaczej, niż wskazywał Anderson, czyli rozwojem nacjonalizmu?

Pod tym względem przytaczane tu krytyki empirycznego narodu oraz nadto uładzonego obrazu "polskości" są próbą zatrzymania ruchu tego koła przez przekierowanie zainteresowania wspólnoty z konstruktu na realną grupę. Jednak, jak pokazuje historia, próby te były zazwyczaj nie tak udane, jak ruch kontrujący: blokowanie wszelkiej formy krytyki przez retoryczny trik, zrównujący rozliczanie empirycznego narodu z jego wad z atakiem na tę wyobrażoną, idealistyczną i tożsamościotwórczą wspólnotę.

Drugim czynnikiem kształtującym postrzeganie polskości jest zatem sposób konstruowania relacji między tymi dwoma bytami, realnym i wyobrażonym. Gdy zakłada się, że ten wyobrażony jest z jednej strony oderwany od empirycznego (a więc nie 
koryguje się tez na temat wspólnoty idealnej na podstawie wspólnoty realnej, ani tym bardziej postrzegania empirycznego narodu, kiedy w małym stopniu przypomina obraz narodu idealnego), z drugiej zaś na tyle kruchy, że każdy rodzaj krytyki godzi nawet nie w jego tożsamość, lecz w jego istnienie, powstaje w pełni hybrydowa, schizofreniczna forma polskości stale zagrożonej, a zarazem nienegocjowalnej i niezmiennej.

Ta całkowicie konstrukcyjna idea, negująca zarazem swój sztuczny charakter, pełni funkcję kagańca i regulatora. Kagańca, bo pod rygorem wyrzucenia poza obręb realnej wspólnoty zabrania nie tylko krytyki, ale nawet refleksji. Regulatora, bo za jej pomocą można bardzo łatwo wyłączać z "polskości” nie tylko jednostki, ale i dowolne cechy, poglądy czy opinie. Przemocowość tak rozumianej polskości jest tyleż nieuchronna, co w pewnym sensie obezwładniająca: skuteczne zniechęca do prób rekonstrukcji z wewnątrz oraz neutralizuje krytykę z zewnątrz jako niewiarygodną, bo antypolską.

Pozostał mi do omówienia trzeci istotny czynnik kształtujący myślenie o polskości. Jest nim to, jak wyobrażamy sobie przyszłość, a szczególnie jak wyobrażamy sobie polskość oraz funkcjonowanie narodu polskiego, i tego realnego, i tego, który może stać się realny dopiero w przyszłości. To ciekawy probierz, pokazujący moim zdaniem naistotniejsze ograniczenie tego hybrydycznego pojmowania polskości, które starałam się omówić: nie ma w nim miejsca na przyszłość. To model, który nie podlega korektom, a więc brakuje w nim przestrzeni na rozwój lub zmianę. Czy idealny naród lub idealną polskość da się poprawić? Czy da się skonfrontować je z mniej lub bardziej trafnie przewidywaną przyszłością i zastanowić się, jak powinny sobie radzić z wyzwaniami? To zadanie trudne do realizacji, jeśli rzeczywiście utożsamia się naród idealny z tym empirycznym. W takim przypadku, nawet jeśli antycypowana jest jakaś przyszłość, odpowiedzią na nią - zarówno na szanse, jakie przed nami otwiera, jak i zagrożenia, które ze sobą niesie - jest ochrona istniejącego stanu rzeczy, realizowana często w formie powrotu do przeszłości, próby ochrony tego, co już zostało zbudowane. Przyszłość w takim modelu jest albo niewyobrażalna, albo niepożądana, a najczęściej jedno i drugie. To, co możliwe do wyobrażenia i zaakceptowania, stanowi powtórzenie przeszłości lub teraźniejszości. To, co realnie inne, stanowi zagrożenie, które należy w jakiś sposób zneutralizować.

Uznanie tak definiowanej wspólnoty wyobrażonej za jedyny rodzaj wspólnoty wart obrony sprawia więc, że nie ma już miejsca na przyszłość ani na wyobraźnię rozumianą jako zdolność postrzegania rzeczy inaczej, niż się aktualnie mają. Na pierwszy rzut oka w takim przypadku przyszłość zostaje wyparta przez przeszłość, przez dążenie do konserwacji określonego stanu rzeczy. Jak jednak pokazuje kolejny blok artykułów w tym numerze, także przeszłość bywa rekonstruowana i pamiętana głównie za pomocą mechanizmu wykluczenia, zapomnienia lub wyparcia. Nie chodzi mi tu o to, że pamięć i wspomnienia mają zawsze charakter selektywny oraz subiektywny, ale że narzucone 
w analizowanym modelu rozumienia polskości ramy bardzo sztywno definiują, co może być pamiętane oraz w jaki sposób.

Zamknięciu na przyszłość towarzyszy nierzadko cenzurowanie przeszłości, starannie budowanej w zasadzie od podstaw, tak by pasowała do anachronicznego pod każdym względem wzorca. Pojęcia kluczowe dla kształtowania tożsamości zbiorowej stają się przedmiotem ahistorycznej rekonstrukcji: naród, wspólnota, społeczeństwo, patriotyzm, polskość, tożsamość, obywatel, wolność, racja stanu etc. Każde z nich traktowane jest jednocześnie esencjalistycznie i konstruktywistycznie. Esencjalistycznie, ponieważ zakłada się, że istnieją od zawsze oraz zawsze znaczyło to samo, a konstruktywistycznie, bo de facto dopuszcza się kolejne redefinicje, tak by zawsze służyły określonym, również politycznym celom.

Jednak jak pokazuje kolejna grupa publikowanych w tym tomie artykułów, przyszłość wymyka się tak zakrojonym rekonstrukcjom, uporczywie będąc czymś in ny m niż teraźniejszość i przeszłość. Nie da się jej zawczasu zmanipulować, ponieważ nie można jej przewidzieć. Można ją sobie jedynie wy o b ra z i ć, a wyobraźnię trudno ująć w ramy i ograniczyć. Siła wyobraźni tkwi w jej powszechności (każdy z nas wyobraża sobie rozmaite rzeczy, jest to więc doświadczenie podzielane powszechnie), a zarazem osobności. Wyobraźnia pozostaje bowiem zasadniczo odmienna od percepcji: percepcja to zdolność postrzegania rzeczy i umiejętność tworzenia na podstawie tego, co doświadczone, obrazów mentalnych. Przywoływanie, powtórne doświadczenie lub przeżycie już raz zaobserwowanego przedmiotu albo doświadczenia nie jest jednak działaniem wyobraźni. To w dalszym ciągu działanie percepcji wzbogaconej o pamięć. Wyobraźnia - jak dowodził między innymi Jean-Paul Sartre - to coś więcej5. To zdolność do manipulowania takim obrazem lub tworzenia obrazu mentalnego, który nie jest jedynie reprezentacją tego, co doświadczone w percepcji, lecz czegoś, co nigdy nie zostało zaobserwowane lub przeżyte.

Dlaczego o tym piszę? Bo wyobraźnia to zdolność do widzenia rzeczy takimi, jakimi nie są ani nie były. To zdolność do wprawienia w ruch tego, co raz zobaczone, by widzieć inaczej. To otwarcie na to, co jeszcze się nie wydarzyło lub nigdy się nie wydarzy. I z wyobraźnią, a zwłaszcza z wyobrażeniem przyszłości, która jest inna, niż to, co już raz doświadczone lub przeżyte, ma bardzo poważny problem każdy dyskurs oraz każdy model polityczny, który dąży do anachronicznego postrzegania kluczowych dla siebie pojęć. Ceną za zagarnięcie przeszłości przez wrzucenie w nią nieistniejących lub odmiennie wtedy rozumianych pojęć jest utrata przyszłości i wyobraźni. Jedyne, co w takim dyskursie pozostaje, to teraźniejszość, ściągnięta i zwężona przez dążenie do zagarnięcia

5 Por. przykład postrzegania i wyobrażania sobie kartki papieru w: J.-P. Sartre Wyobraźnia, przeł. A. Śpiewak, P. Mróz, Aureus, Kraków 1998, s. 25. 
jak największych połaci czasu. Paradoksalnie, próba okradzenia przeszłości z tego, czym była w swej odmienności, kończy się nie zyskiem, ale stratą: nieprzekraczalną blokadą w próbach wyobrażenia sobie przyszłości, które, nawet jeśli są podejmowane, zawsze kończą się tym samym - zamknięciem w anachronicznym teraz.

Prezentowane w tym numerze artykuły dostarczają szeregu kluczy i wytrychów ułatwiających otwarcie przeszłości oraz przyszłości, a także zmierzenie się z doświadczeniami kryzysowymi lub niemożliwymi. Trudno z nich ułożyć spójną całość, bo każdy z tych tekstów odpowiada na odmienne potrzeby, inaczej konceptualizując to, co jest obecnie najważniejsze na przecięciu sfery publicznej i prywatnej, na granicy jednostkowej wyobraźni oraz podzielanej przeszłości i teraźniejszości (kwestia polskości, manipulacji przeszłością, konieczności konfrontacji z nieuładzoną pamięcią o przeszłości, konsekwencje tworzenia alternatywnych rzeczywistości, doświadczenie kryzysu i doświadczenie niemożliwe, a także wyzwanie budowania wspólnotowej wizji przyszłości to tylko niektóre poruszane w tym numerze wątki). Wskazują one jednak niezbicie, że sztuka i kultura - ponownie odmiennie definiowane - są wentylem bezpieczeństwa pozwalającym na ćwiczenie wyobraźni.

Choć wszelkie przewidywania oraz wyobrażenia na temat przyszłości obarczone są sporym ryzykiem błędu - co ten rok pokazałaż nazbyt dobitnie - największym błędem jest niewyobrażanie sobie przyszłości oraz wiara w to, że będzie ona wyglądała tak, jak teraźniejszość. Ćwiczenie wyobraźni może pomóc nie tylko przetrwać czas, kiedy wydajemy się zamknięci w teraźniejszości, ale również zacząć patrzeć na przyszłość jako na ten aspekt szeroko rozumianej polityki, który powinien nas interesować najbardziej, także jako test i probierz teraźniejszych działań. 


\section{Abstract}

\section{Justyna Tabaszewska}

THE INSTITUTE OF LITERARY RESEARCH OF THE POLISH ACADEMY OF SCIENCES (WARSAW)

Beyond the Imagination, Above Politics

This introduction to the issue 6/2020 of "Teksty Drugie" explores the mutual interdependence of the imagination and politics. Tabaszewska demonstrates that political systems and models that present their own key terms (such as "the nation") as anachronistic struggle with the task of imagining a future, thus narrowing their chances to lay the ground for a future that would be radically different than the present or the past.

\section{Keywords}

imagination, politics, anachronism, future, nationalism 